\title{
SEGMENTASI PEMILIH PEMULA BERDASARKAN AKSES BERITA POLITIK MELALUI MEDIA SOSIAL DI KABUPATEN BOGOR
}

\author{
Beginner Segmentation Segmentation based on Access to Political News \\ through Social Media in Bogor District
}

\author{
Roni Jayawinangun ${ }^{1}$, David Rizar Nugroho ${ }^{2}$ \\ ${ }^{1}$ Universitas Pakuan Bogor \\ ${ }^{2}$ Universitas Pakuan Bogor \\ E-mail: winangun.roni@gmail.com
}

\begin{abstract}
Political participation is an important problem because it is one form of support that comes from various parties or groups. Political participation is inseparable from the media as a means of information for the community. Beginner voters are one part of the community whose voice is needed in the political process. Beginner voters with media are two things that cannot be separated, especially the use of social media. The research objective consists of several things, namely: 1). Knowing the characteristics of beginner voters in Bogor Regency; 2). Knowing the use of social media in accessing political news on beginner voters; 3). Analyzing the political typology of beginner voters; 4). Analyzing the segmentation of beginner voter typology based on access to political news on social media. This study used a survey approach and data collection using a questionnaire on 105 respondents. The sampling method uses quota sampling while the data analysis uses descriptive analysis, mean scores and CHAID. The results of this study indicate that the characteristics of beginner voters in Bogor Regency are dominated by women, high school education, not participating in the organization. Instagram is the most widely used social media as access to political news. The typology of beginner voters from the largest percentage is apathetic voters followed by naive, alienated and loyal voters, the media, the more access to news through social media encourages voters to be loyal, without accessing politics through social media makes voters apathetic.
\end{abstract}

Keywords: social media, beginner voter, election

ABSTRAK
Partisipasi politik adalah suatu masalah penting karena merupakan salah satu bentuk
dukungan yang datang dari berbagai pihak atau golongan. Partisipasi politik tidak terlepas
dari media sebagai sarana informasi bagi masyarakat. Pemilih pemula merupakan salah
satu bagian dari masyarakat yang suaranya diperlukan dalam proses politik. Pemilih
pemula dengan media merupakan dua hal yang tidak bisa dipisahkan khususnya
penggunaan media sosial. Tujuan penelitian terdiri dari beberapa hal yaitu: 1) Mengetahui
karakteristik pemilih pemula di Kabupaten Bogor; 2) Mengetahui penggunaan media
sosial dalam mengakses berita politk pada pemilih pemula; 3) Menganalisis Tipologi
politik pemilih pemula; 4) Menganalisis segmentasi tipologi pemilih pemula berdasarkan
akses berita politik pada media sosial.Penelitian ini menggunakan pendekatan survei dan
pengumpulan data menggunakan kuesioner pada 105 responden. Metode sampling
menggunakan quota sampling sedangkan analisis data menggunakan analisis deskriptif,
skor rataan dan CHAID. Hasil dari penelitian ini menujukan bahwa karakteristik pemilih
pemula di Kabupaten Bogor didominasi wanita, pendidikan SLTA, tidak berpartisipasi
pada organisasi. Instagram adalah media sosial yang paling banyak digunakan sebagai
akses berita politik. Tipologi pemilih pemula dari persentase yang paling besar adalah
pemilih apatis diikuti oleh pemilih naif, teralienasi dan setia, media, semakin banyak


akses berita melalui media sosial mendorong pemilih menjadi setia, tanpa mengakses politik melalui media sosial membuat pemilih menjadi apatis.

Kata kunci: media sosial, pemilih pemula, pemilu

\section{PENDAHULUAN}

Pemilihan umum (pemilu) merupakan salah satu pilar demokrasi untuk menyelaraskan kebijakan pemerintah serta pembangunan berdasarkan kehendak rakyat, sebagai pemilik kedaulatan. Disahkannya Undang-undang No. 32 Tahun 2004 tentang Pemerintahan Daerah yang merupakan revisi dari Undang-undang No. 22 Tahun 1999, telah mengubah tata cara pemilihan kepala daerah. Kepala daerah yang sebelumnya dipilih oleh Dewan Perwakilan Rakyat Daerah (DPRD) diubah menjadi dipilih langsung oleh masyarakat. Ketentuan ini tertuang dalam pasal 56 ayat 1 undang-undang tersebut yaitu, 'Kepala daerah dan wakil kepala daerah dipilih dalam satu pasangan calon yang dilaksanakan secara langsung, umum, bebas, rahasia, jujur dan adil'.Pemilu dengan partisipasi tidak dapat dipisahkan, karena salah satu indikator keberhasilan dari Pemilu adalah tingkat partisipasi masyarakat.

Partisipasi politik yang menarik untuk dijadikan kajian adalah partisipasi politik para pemilih pemula, karena pemilih pemula adalah kalangan yang baru memasuki dunia politik sehingga informasi tentang politik masih minim. Pada Pemilu 2014, diketahui bahwa 63\% dari pemilih tinggal di Pulau Jawa, dimana 19,7 juta diantaranya adalah pemilih pemula dengan rentang usia 17-21 tahun dan $57 \%$ diantaranya adalah pemilih muda yang akrab dengan penggunaan media (Perangin-angin dan Zainal, 2018). Jika dilihat pemaparan dari Komisioner KPU Jabar Divisi SDM dan Hubungan Partisipasi Masyarakatjumlah pemilih pemula diperkirakan kuantitas di Jawa Barat mencapai 30\% (Chandra, 2018). Besarnya potensi pemilih pemula merupakan tantangan tersendiri bagi penyelenggara pemilu, yaitu KPU untuk menginformasikan berita politik untuk mendorong kelompok ini terlibat dalam pemilihan.

Pemilih pemula tidak dapat dipisahkan dari media baru, khususnya media sosial. Salah satu yang menjadi faktor pendorong dalam partisipasi politik adalah penggunaan media berdasarkan penelitian Saldana, McGregor, and Zuniga, (2015). Penggunaan media yang marak saat ini adalah adalah media baru, yaitu internet. Lembaga survei Gallup (2012) dalam salah satu laporannya menyebutkan bahwa satu dari lima orang di Indonesia (20.6\%) menggunakan internet dalam kehidupan mereka, dan dewasa ini, lebih dari setengah $(51 \%)$ penduduk muda Indonesia yang berusia antara 15-24 tahun telah menggunakan internet dalam aktivitas mereka. Sebagian besar penduduk muda ini $(96.2 \%)$ adalah pengguna media sosial. Hasil survey globalwebindex dikutip dari katadata (2018) pengguna internet di Indonesia dalam rentang usia 16-64 tahun, menunjukkan bahwa ada beberapa platform media sosial yang aktif digunakan oleh masyarakat Indonesia. Platform media jejaring sosial yang paling besar adalah Youtube dengan persentase penggunaan sebesar $43 \%$, di peringkat ke duaFacebook dengan persentase penggunaan sebesar $41 \%$, kemudian instagram dengan persentase penggunaan sebesar $38 \%$. Begitu eratnya pemilih pemula dengan media sosial maka menarik untuk membagi/segmentasi pemilih pemula ini berdasarkan tipologi pemilih berdasarkan ketertarikan terhadap politik dan kepercayaan politik. 
Menurut Lehmann dan Eherler (2000), salah satumetode dependensi yang sering digunakan dalamsegmentasi pasar adalah analisis CHAID (Chi-Squared Automatic Interaction Detection analysis).Dalam penelitian ini, analisis CHAID digunakan untuk menentukan segmentasi pemilih pemula di Kabupaten Bogor.Tujuan dari segmentasi ini adalah mengidentifikasisegmen berdasarkan tipologi pemilih berdasarkan ketertarikan terhadap politik dan kepercayaan politik serta akses berita politik di Media Sosial.

Kabupaten Bogor adalah salah satu Daerah yang melakukan pemilihan pemilihan kepala daerah Tahun 2018, selain itu Kabupaten Bogor adalah Kabupaten dengan jumlah penduduk terbesar di Jawa Barat. Menjadi hal yang menarik untuk mengetahui segmentasi pemilih pemula berdasarkan akses media sosial.

Penelitian ini diharapkan dapat memberikan manfaat kepada Pemerintah, dalam hal ini adalah KPU sebagai input atau masukan untuk sosialisasi dalam meningkatkan partisipasi pemilih pemula dan bagi Peneliti untuk memahami tipologi dan dampak dari akses berita politik melalui media sosial pada pemilih pemula. Adapun tujuan dari penelitian ini adalah 1) Mengetahui karakteristik pemilih pemula di Kabupaten Bogor, 2) Mengetahui penggunaan media sosial dalam mengakses berita politikpada pemilih pemula di Kabupaten Bogor, 3) Menganalisis tipologi pemilih pemula di Kabupaten Bogor, dan 4) Menganalisis segmentasi tipologi pemilih pemula berdasarkan akses berita politik melalui media sosial di Kabupaten Bogor.

\section{METODE PENELITIAN}

Penelitian ini dilakukan di enam daerah pemilihan (dapil) Kabupaten Bogor yang meliputi 40 Kecamatan yaitu Dapil 1 yang terdiri dari lima Kecamatan, Dapil 2 terdiri dari enam Kecamatan, Dapil 3 terdiri dari tujuh Kecamatan, Dapil 4 terdiri dari enam Kecamatan, Dapil 5 terdiri dari sembilan Kecamatan dan Dapil 6 terdiri dari tujuh tujuh Kecamatan. Waktu penelitian dilakukan selama 6 bulan.

Penelitian ini dilaksanakan dengan menggunakan dua pendekatan, yaitu pendekatan survai bersifat deskriptif untuk menjelaskan bagaimana karakteristik, penggunaan media sosial pemilih pemula di Kabupaten Bogor, serta untuk mengelompokan pemilih ke dalam tipologi pemilih. Populasi dari penelitian ini adalah 30 persen dari total pemilih yang terdaftar di KPUD Kabupaten Bogor pada Pilkada Serentak Tahun 2018 yaitu sebanyak 988.448 orang. Sampel pada penelitian ini adalah laki-laki yang sudah memiliki hak pilih sesuai aturan yang berlaku yaitu Warga Negara Indonesia, usia terendah 17 tahun sampai 21 tahun atau sudah kawin, dan terdaftar sebagai pemilih di Kabupaten Bogor.

Data yang digali dalam penelitian ini adalah data primer dan data sekunder. Data primer diperoleh dari pengisian kuesioner oleh responden secara langsung dan juga wawancara singkat. Data sekunder yang yang akan digunakan dari dokumen-dokumen dari instansi seperti Komisi Pemilihan Umum (KPU) baik tingkat pusat mupun Kabupaten, Badan Pusat Statistika, literatur, dan hasil penelitian yang relevan terhadap penelitian ini.

Metode pengumpulan data menggunakan quota sampling berdasarkan wilayah Daerah Pemilihan. Penentuan jumlah responden menggunakan rumus slovin dengan tingkat error sebesar 10 persen dan jumlah populasi sebesar 988.448 
orang maka didapatkan jumlah sampel minimal sebanyak 100 responden dan akan ditambahkan menjadi 105 responden. Pembagian responden berdasarkan wilayah dapat dilihat pada Tabel 1 berikut.

Tabel 1 Pembagian responden berdasarkan wilayah

\begin{tabular}{cccc}
\hline DAPIL & Jumlah Pemilih & Porsi (\%) & Responden \\
\hline BOGOR 1 & 174.104 & 17,6 & 18 \\
BOGOR 2 & 167.926 & 17,0 & 18 \\
BOGOR 3 & 147.804 & 15,0 & 16 \\
BOGOR 4 & 154.172 & 15,6 & 16 \\
BOGOR 5 & 182.720 & 18,5 & 19 \\
BOGOR 6 & 161.721 & 16,4 & 17 \\
\hline TOTAL & 988.448 & 100,0 & 105 \\
\hline
\end{tabular}

Sumber: KPU Kabupaten Bogor, 2018

Data yang dikumpulkan dalam penelitian ini diolah dan dianalisis dengan prosedur sebagai berikut:

1. Analisis deskriptif digunakan untuk menggambarkan sesuatu yang tengah berlangsung pada saat riset dilakukan dan memeriksa sebab-sebab dari suatu keadaan atau gejala tertentu. Analisis deskriptif ini digunakan dalam menggambarkan karakteristik responden, dan penggunaan media sosial dalam mengakses berita politik

2. Analisis Skor Rataan

Skor rataan digunakan untuk mengelompokkan jawaban responden terhadap masing-masing kriteria menggunakan skala likert dengan lima tingkatan.Hasilnya dikuantitatifkan ke dalam bentuk skor rataan dari masingmasing responden untuk mengelompokan atau segmentasi pemilih pemula.

3. Analisis CHAID

Analisis CHAID digunakan untuk melakukan segmentasi. Segmentasi biasanya dilakukan pada bidang pemasaran untuk melihat peta pasar produk di mata konsume. Prinsip yang sama digunakan pada penelitian ini. Produk dianalogikan dengan tipologi pemilih berdasarkan ketertarikan politik dan kepercayaan terhadap insitusi politik dan akses politik melalui media sosial.

\section{HASIL DAN PEMBAHASAN}

\section{Karakteristik Pemilih Pemula}

Karakteristik pada penelitian ini meliputi jenis kelamin, usia, pendidikan, partisipasi organisasi, dan aktivitas. Berdasarkan data yang diperoleh, diketahui bahwa sebagian besar responden adalah perempuan dengan persentase sebesar 62,9 persen dan sisanya adalah laki-laki dengan persentase sebesar 37 persen. Hal ini menunjukan bahwa perempuan lebih terbuka dan bersedia untuk diminta keterangan terkait dengan partisipasi politik dibandingkan laki-laki, selain itu berdasarkan hasil pemilu serentak tahun 2018 diketahui secara umum di Provinsi Jawa Barat dan Kabupaten Bogor tingkat partisipasi wanita lebih besar dibandingkan laki-laki.

Jika dilihat berdasarkan usia, diketahui bahwa persentase terbesar adalah usia 20 tahun dengan persentase sebesar 40 persen, diikuti usia 21 dam 19 sebesar 20 persen. Berdasarkan pendidikan, maka diketahui bahwa responden didominasi pendidikan terakhir SLTA sebesar 83,8 persen, diikuti SLTP sebesar 11,4 persen dan sisanya adalah SD sebesar 3,8 persen dan Sarjana sebesar 1 persen. 
Berdasarkan partisipasi organisasi diketahui bahwa sebagian besar responden tidak berpartisipasi pada organisasi apapun yaitu sebesar 61 persen, sedangkan sisanya sebesar 39 persen pernah atau masih terlibat dalam organisasi. Hal ini menujukan bahwa pemilih pemula di Kabupaten Bogor tidak terlalu aktif dalam partisipasi dalam kelembagaan atau organisasi. Berdasarkan aktivitas, diketahui sebagian besar adalah pelajar atau mahasiswa dengan persentase sebesar 83,8 persen. Hal ini dikarenakan memang aktivitas utama dari pemilih pemula adalah belajar.

\section{Penggunaan Media Sosial dalam mengakses Berita Politik Pada Pemilih Pemula}

Media sosial dalam kontekspenelitian ini adalah jejaring sosial yang dipakai dalam mengakses berita politik meliputi jenis media sosial dan akses berita dalam mencari informasi terkait berita dan perkembangan politik. Persentase kepemilikan dan akses berita politik melalui media sosial dapat dilihat pada Gambar 2.

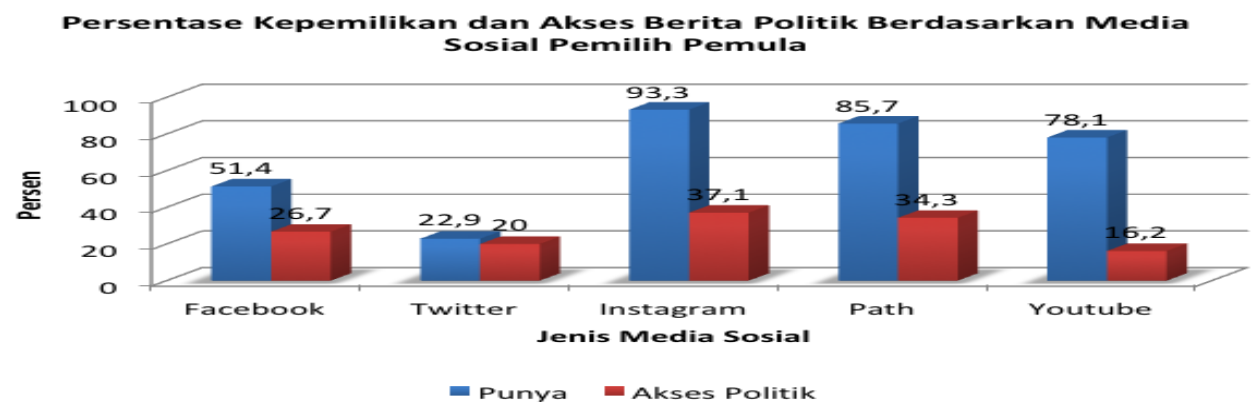

Gambar 1 Persentase kepemilikan dan akses berita politik melalui media sosial pemilih pemula

Berdasarkan Gambar 2, diketahui kepemilikan paling besar adalah instagram sebesar 93,3\%, diikuti path sebesar 85,7\%, Youtube 78,1\%, Facebook $51,4 \%$ dan twitter sebesar $22,9 \%$. Jika dilihat berdasarkan keaktifan mengakses berita politik, diketahui bahwa instagram adalah yang paling besar dengan persentase sebesar 37,11 persen, diikuti path $(34,3 \%)$, facebook $(26,7 \%)$ dan twitter (20\%). Hal ini menunjukan bahwa media sosial belum dapat mempengaruhi ketertarikan pemilih pemilih pemula terhadap dunia politik, seperti hasil penelitian CSIS (2017) yang menyebutkan bahwa pengaruh generasi milenial dalam aspek politik dan ekonomi belum terlalu kuat, namun bila informasi di media sosial semakin dapat dipercaya, akan membentuk generasi yang lebih kuat.

\section{Tipologi dan Pemilih Pemula di Kabupaten Bogor}

Tipologi yang digunakan pada penelitian ini terdiri dari dua bagian yaitu kepercayaan terhadap institusi politik dan efikasi yang menghasilkan empat jenis pemilih, yaitu pemilih apatis, pemilih naif, pemilih terelinasi dan pemilih setia menurut Seligson (1980). Hasil tipologi pemilih pemula dapat dilihat pada Tabel 2 berikut. 
Tabel 2 Konfigurasi tipologi pemilih pemula Kabupaten Bogor

\begin{tabular}{l|l|ll} 
& $\begin{array}{l}\text { Pemilih Teralienasi } \\
(14,3 \%)\end{array}$ & $\begin{array}{l}\text { Pemilih Setia } \\
(13,3 \%)\end{array}$ & \\
\cline { 2 - 4 } $\begin{array}{l}\text { Ketertarikan Politik } \\
\text { Rendah }\end{array}$ & $\begin{array}{l}\text { Pemilih Apatis } \\
(52,4 \%)\end{array}$ & $\begin{array}{l}\text { Pemilih Naif } \\
(20,0 \%)\end{array}$ & \\
\cline { 2 - 4 } & Rendah $\quad$ Kepercayaan Institusi $\quad$ Tinggi
\end{tabular}

Berdasarkan Tabel 2, diketahui bahwa pemilih pemula di Kabupaten Bogor merupakan pemilih apatis dengan persentase sebesar $52,4 \%$, diikuti oleh pemilih naif sebesar $20 \%$, pemilih teralienasi sebesar $14,3 \%$ dan pemilih setia sebesar 13,3\%. Urutan ini sesuai dengan survei lembaga politik indikator Tahun 2013 yang menyebutkan bahwa pemilih apatis sebesar $41,5 \%$, diikuti pemilih naif $(28,3 \%)$, pemilih setia (17\%) dan pemilih terelinasi $(13,2 \%)$. Hal ini sesuai dengan hasil penelitian dari Alvara research center tahun 2018 yang menyebutkan bahwa salah satu perilaku milenial Indonesia adalah cuek dengan politik (Ali, 2018). Hal ini menunjukkan bahwa masih banyak pemilih pemula di Kabupaten Bogor yang melihat pemilu sebagai sesuatu tidak menarik.

\section{Tipologi dan Akses Berita Politik melalui Media Sosial Pemilih Pemula}

Berdasarkan hasil analisis CHAID, diketahui bahwa tipologi dapat diklasifikasikan menjadi 5 (lima) kelompok berdasarkan akses berita politik melalui media sosial. Dari lima platform media sosial, hanya empat platform penjelas yang berpengaruh terhadap tipologi pemilih yaitu instagram, facebook, youtube dan path. Berdasarkan hasil analisis CHAID diketahui bahwa pemilih dapat diklasifikasikan menjadi lima kelompok yaitu:

Tabel 3 Pengklasifikasian berdasarkan diagram pohon CHAID

\begin{tabular}{ccl}
\hline Klasifikasi & Node & \multicolumn{1}{c}{ Keterangan } \\
\hline 1 & 1,3 dan 7 & $\begin{array}{l}\text { Tipologi apatis yaitu pemilih yang tidak mengakses berita } \\
\text { politik melalui media sosial }\end{array}$ \\
2 & 1,3 dan 8 & $\begin{array}{l}\text { Tipologi apatis yaitu pemilih yang mengakses berita } \\
\text { politik melalui path } \\
\text { Tipologi naif yaitu pemilih yang mengakses berita politik } \\
\text { melalui facebook } \\
\text { Tipologi teralienasi yaitu pemilih yang mengakses berita } \\
\text { politik melalui instagram } \\
\text { Tipologi setia yaitu pemilih yang mengakses berita politik } \\
\text { melalui instagram dan youtube }\end{array}$ \\
\hline
\end{tabular}

Dari Tabel 3, dapat diketahui bahwa kelompok 1 dan 2 adalah tipologi pemilih pemula yang apatis yaitu pemilih yang tidak mengakses berita politik melalui media sosial apapun dan hanya menggunakan path, hal ini dikarenakan sifat tertutup media sosial path sehingga informasi yang diberikan terbatas. Kelompok 3 adalah kelompok pemilih pemula naif yaitu pemilih yang mengakses berita politik hanya melalui media sosial facebook. Kelompok 4 adalah kelompok tipologi teralienasi yaitu pemilih yang mengakses berita politik menggunakan instagram, hal ini dikarenakan instagram merupakan platform media sosial yang paling sering digunakan oleh pemilih pemula dan juga banyaknya informasi yang disajikan. Kelompok 5 adalah tipologi pemilih setia, yaitu pemilih yang mengakses berita politik melalui platform media sosial instagram dan youtube, hal 
ini menunjukan semakin banyak platform yang digunakan dapat mendorong pemilih menjadi setia. Keakuratan dari prediksi ini dengan menggunakan risk yang digunakan untuk menuguji kebaikan model. Estimasi menunjukkan nilai 0.381 atau risiko sebesar $38,1 \%$, hal ini memiliki arti bahwa model akan salah memprediksi atau salah mengklasifikasi tipologi pemilih sebesar 38,1\%.

Tabel 4 Output risk

\begin{tabular}{|c|cc|}
\multicolumn{1}{c}{ Risk } \\
\hline Estimate & Std. Error \\
\hline .381 & & .047 \\
\hline \multicolumn{2}{|c|}{ Growing Method: CHAID } \\
Dependent Variable: tipologi
\end{tabular}

Berdasarkan hasil tersebut maka diketahui bahwa mengakses berita politik lebih dari satu platform media sosial yaitu melalui instagram danyoutubedapat mendorong pemilih muda menjadi setia, sedangkan tanpa mengakses berita politik dari media sosial akan mendorong pemilih pemula menjadi pemilih apatis. Kelompok pemilih pemula yang apatis yaitu pemilih yang hanya mengakses berita politik dari satu platform (facebook dan instagram) tanpa diperkuat/validasi informasi dari platform media sosial yang lain dapat mendorong pemilih pemula menjadi naif dan teralienasi.

\section{KESIMPULAN DAN SARAN}

Berdasarkan penelitian ini, maka:

1. Karakteristik pemilih pemula di Kabupaten Bogor didominasi jenis kelamin wanita, dengan pendidikan SLTA, tidak berpartisipasi pada organisasi dan mempunyai aktivitas sebagai pelajar atau mahasiswa.

2. Penggunaan media social dalam mengakses berita politikpada pemilih pemula di Kabupaten Bogor diketahui bahwa instagram adalah yang paling besar dengan persentase diikuti path, facebook, Twitter dan youtube.

3. Tipologi pemilih pemula di Kabupaten Bogor dari persentase yang paling besar adalah pemilih apatis diikuti oleh pemilih naif, pemilih setia dan pemilih teralienasi.

4. Segmentasi tipologi pemilih pemula berdasarkan akses berita politik melalui media sosial di Kabupaten Bogordiketahuimengakses berita politik lebih dari satu platform media sosial yaitu melalui instagram dan youtube dapat mendorong pemilih muda menjadi setia, sedangkan tanpa mengakses berita politik dari media sosial akan mendorong pemilih pemula menjadi pemilih apatis. Kelompok pemilih pemula yang apatis yaitu pemilih yang hanya mengakses berita politik dari satu platform (facebook dan instagram) tanpa diperkuat/validasi informasi dari platform media sosial yang lain dapat mendorong pemilih pemula menjadi naif dan teralienasi.

\section{DAFTAR PUSTAKA}

Ali, H. 2018. 9 Perilaku Milenial Indonesia. [pdf document]. Diakses dari http://www.academia.edu/35915408/MEMAHAMI_MILENIAL_INDONE SIA_by._Alvara_Research_Center tanggal akses 12 September 2018

Chandra, F. 2018. Pemilih Muda Dituntut Bertanggungjawab. Tersedia http://jabar.kpu.go.id/2018/04/pemilih-muda-dituntut-bertanggungjawab/. Diakses pada 11 september 2018 
CSIS. 2017. Ada Apa dengan Milenial? Orientasi Sosial, Ekonomi dan Politik. [pdf document]. Diakses dari https://www.csis.or.id/uploaded_file/event/ ada_apa_dengan_milenial_paparan_survei_nasional_csis_mengenai_orient asi_ekonomi_sosial_dan_politik_generasi_milenial_indonesia_notulen.pdf tanggal akses 21 September 2018

Firmanzah. 2012.Marketing Politik : Antara Pemahaman dan Realitas. Jakarta: Yayasan Obor.

Gallup. 2012. Media Use in Indonesia 2012. Broadcasting Board of Governor [PDF document]. Retrieved from http://www.bbg.gov/wpcontent/media/2012/10/gallup- indonesia-brief.pdf

Hapsari, Dwi R. 2012. Pemanfaatan informasi oleh petani sayuran (Kasus di Desa Ciaruteun Ilir, Kecamatan Cibungbulang, Kabupaten Bogor) [tesis]. Bogor (ID): Sekolah Pascasarjana IPB.

Indikator Politik Indonesia. 2013. Internet, Apatisme, dan Alienasi Politik Temuan Survei Nasional. Survei Nasional Juni 2013.

Komisi Pemilihan Umum. 2018. Daftar Pemilih Tetap Pilkada Serentak Tahun 2018. [serial online]. tersedia di https://infopemilu.kpu.go.id/pilkada2018/pemilih/dpt/1/JAWA\%20BARAT diakses tanggal 11 September 2018.

Martha, Layung P. 2015. Hubungan Penggunaan Sumber Informasi Kampanye dan Partisipasi Politik (Kasus Pilpres 2014 di Kecamatan Cibinong Bogor) [tesis]. Bogor (ID): Sekolah Pascasarjana IPB.

Perangin-angin, LLK \& Zainal, M. 2018. Partisipasi Politik Pemilih Pemula Dalam Bingkai Jejaring Sosial di Media Sosial. Jurnal Aspikom Vol 3 No. 4 hal 737-754.

Kaplan, AM., Haenlein, M. 2010. User of the World, Unite! The Challenges and Opportunities of Social Media, Majalah Business Horizons: hal: 69-68

Katadata.2018. Media yang paling sering digunakan di Indonesia. Tersedia https://databoks.katadata.co.id/datapublish/2018/02/01/media-sosial-apayang-paling-sering-digunakan-masyarakat-indonesia. Diakses pada Tanggal 11 September 2018.

Lehmann, T. dan Eherler, D. 2001. Responder Profilingwith CHAID and Dependency Analysis.www.informatik.uni-freiburg.de/ ml/ecmlpkdd/WSProceedings/w10/lehmann.pdf. Diakses tanggal 11September 2018.

Saldana M., Shan non, C. M., \& Homero, G. D. Z. 2015. Social Media as a Public Space for Politics: Cross - National Comparison of News Consumption and Participatory Behaviors in the United State and the United Kingdom. International Journal of Communication 9 (2015). 3304 3326

Severin WJ, Tankard Jr JW. 2011. Teori Komunikasi (Sejarah, Metode dan Terapan di dalam Media Massa). Jakarta [ID]: Kencana Prenada Media Group.

Seligson MA. 1980. Trust, Efficacy and Modes of Political Participation: A Study of Costa Rican Peasants [disertasi]. Cambridge (UK) : Cambridge University. 